\title{
Prognostic Significance of the Decreased Rate of Perioperative Serum Carcinoembryonic Antigen Level in the Patients With Colon Cancer After a Curative Resection
}

\author{
Tae Doo Jung, Jong Han Yoo, Min Jae Lee, Ha Kyung Park, Jae Ho Shin, Min Sung An, Tae Kwun Ha, \\ Kwang Hee Kim, Ki Beom Bae, Tae Hyeon Kim, Chang Soo Choi, Min Kyung Oh ${ }^{1}$, Kwan Hee Hong \\ Department of Surgery, Inje University Busan Paik Hospital, ${ }^{1}$ Clinical Trial Center in Pharmacology, Inje University College of Medicine, \\ Busan, Korea
}

Purpose: The serum level of carcinoembryonic antigen (CEA) is a clinical prognostic factor in the follow-up evaluation of patients with colon cancer. We aimed to evaluate the prognostic significance of the rate of decrease of the perioperative serum CEA level in patients with colon cancer after a curative resection.

Methods: A total of 605 patients who underwent a curative resection for colon cancer between January 2000 and December 2007 were enrolled retrospectively. The rate of decrease was calculated using the following equation: ([preoperative CEA - postoperative CEA]/[preoperative CEA] $\times 100$ ).

Results: In the group with a preoperative serum CEA level of $>5 \mathrm{ng} / \mathrm{mL}$, the normalized group with a postoperative serum CEA level of $\leq 5 \mathrm{ng} / \mathrm{mL}$ showed a better overall survival (OS) rate and disease-free survival (DFS) rate than those of the nonnormalized group $(\mathrm{P} \leq 0.0001)$. The "cutoff values" of the rate of decrease in the perioperative serum CEA that determined the OS and the DFS were $48.9 \%$ and $50.8 \%$, respectively. In the multivariate analysis of preoperative serum CEA levels $>5$ $\mathrm{ng} / \mathrm{mL}$, the prognostic factors for the OS and the DFS were the cutoff value $(\mathrm{P}<0.0001)$ and the $\mathrm{pN}$ stage $(\mathrm{P}<0.0001)$.

Conclusion: A rate of decrease of more than $50 \%$ in the perioperative serum CEA level, as well as the normalization of the postoperative serum CEA level, may be useful factors for determining a prognosis for colon cancer patients with high preoperative CEA levels.

Keywords: Colon neoplasms; Carcinoembryonic antigen; Prognostic factor

\section{INTRODUCTION}

Colorectal cancer (CRC) remains the leading cause of cancer-related deaths worldwide, and the TNM classification is the best prognostic predictor of outcomes in patients with CRC [1-3]. However, factors such as the TNM classification cannot be readily obtained preoperatively. In spite of the many investigations of prognostic factors in CRC, few parameters are predictive of the risk of

Received: March 27, 2013 - Accepted: May 24, 2013

Correspondence to: Min Sung An, M.D.

Department of Surgery, Inje University Busan Paik Hospital, Inje University College of Medicine, 75 Bokji-ro, Busanjin-gu, Busan 614-735, Korea Tel: +82-51-890-6349, Fax: +82-51-898-9427, E-mail: gsams@paik.ac.kr

(C) 2013 The Korean Society of Coloproctology

This is an open-access article distributed under the terms of the Creative Commons Attribution NonCommercial License (http://creativecommons.org/licenses/by-nc/3.0) which permits unrestricted noncommercial use, distribution, and reproduction in any medium, provided the original work is properly cited. tumor relapse in individual patients. An accurate prognostic parameter before surgery is important, and when preoperative prognostic factors or high risks of tumor relapse are present in patients with CRC, different treatment approaches are required.

Tumor markers have been applied in clinical practice for several decades, including in the diagnosis, screening, staging, and monitoring of the effects of treatments [1, 2, 4-6]. Since its initial description in 1965 by Gold and Freedman [7], carcinoembryonic antigen (CEA) has been the tumor marker investigated most extensively for CRC. Indeed, many studies have demonstrated the prognostic value of the preoperative CEA level after surgical colon resection [8-11]. However, the early postoperative decrease in the CEA level, as compared with the preoperative CEA level, as an independent predictor of disease-free survival (DFS) and overall survival (OS) in patients with colon cancer has been evaluated only rarely. Therefore, we analyzed the prognostic values by evaluating the preoperative serum CEA level and the perioperative rate of 
decrease in serum CEA level in patients who underwent a curative resection for colon cancer.

\section{METHODS}

Between January 2000 and December 2007, 895 patients with primary colon cancer underwent a surgical resection in the Department of Surgery, Inje University Busan Paik Hospital, Inje University College of Medicine. All patients who had undergone a surgical resection for colon cancer were registered in a prospectivelycollected colon-cancer database and were followed up. Six hundred five patients with pathological stages I to III tumors were included in this study. Patients with distant metastasis, palliative resection, or no information on the preoperative serum CEA levels were excluded. All patients underwent a surgical resection with a laparotomy or laparoscopic surgery. Serum CEA levels were measured in the preoperative period and within 1 month postoperatively. Adjuvant therapy was given to patients with pathologic stage II and III colon cancer. Chemotherapy comprised 5-fluorouracil (5-FU) and leucovorin with or without oxaliplatin. The 1st regimen was to give 5-FU $\left(425 \mathrm{mg} / \mathrm{m}^{2}\right)$ and leucovorin $(20 \mathrm{mg} /$ $\mathrm{m}^{2}$ ) daily for 5 days every 4 weeks for 6 cycles. The 2 nd regimen was to give oxaliplatin $\left(85 \mathrm{mg} / \mathrm{m}^{2}\right)$ on the first day and leucovorin $\left(200 \mathrm{mg} / \mathrm{m}^{2}\right)$ before 5 -FU injection on days 1 and 2 and 5-FU (400 $\mathrm{mg} / \mathrm{m}^{2}$ by bolus and $600 \mathrm{mg} / \mathrm{m}^{2}$ over 22 hours) in days 1 and 2 every 2 weeks for 12 cycles. No adjuvant chemotherapy was administered to patients who refused chemotherapy, were older than 75 years of age, or showed a poor performance status.

Patients were followed up every 3 months for the first 2 years after surgery and every 6 months thereafter for 3 years, for a total 5 -years' follow-up. History, physical examination, and serum CEA level were determined at each follow-up visit. Chest X-ray and abdominopelvic computed tomography were performed at 6-month intervals, and colonoscopy was performed annually. Recurrence was identified by imaging studies and colonoscopy and was confirmed by colonoscopic or percutaneous biopsy. When histologic confirmation was not possible, radiologically-observed tumor growth within the previous surgical field was considered to indicate recurrence.

Categorical variables were compared using a chi-square test or a Fisher exact test. The Kaplan-Meier method was conducted to evaluate the OS and the DFS rates. Prognostic factors for OS and DFS were analyzed with a log-rank test, and a multivariate analysis was performed using a Cox proportional hazard model. A Pvalue of $<0.05$ was considered to indicate statistical significance. Statistical analyses were conducted using SAS ver. 9.2 (SAS Institute Inc., Cary, NC, USA).

\section{RESULTS}

\section{Clinical and pathological characteristics}

The clinicopathologic characteristics of the colon-cancer patients are shown in Table 1. A high preoperative serum CEA level $(>5$ $\mathrm{ng} / \mathrm{mL}$ ) was found in 177 of the 605 patients (29.26\%). Sixty-nine

Table 1. Clinicopathological characteristics of colon cancer $(n=605)$

\begin{tabular}{|c|c|}
\hline Characteristic & Value \\
\hline \multicolumn{2}{|l|}{ Sex } \\
\hline Female & $272(45.03)$ \\
\hline Male & $333(54.97)$ \\
\hline \multicolumn{2}{|l|}{ Age (yr) } \\
\hline$<59$ & $217(35.87)$ \\
\hline$\geq 60$ & $388(64.13)$ \\
\hline \multicolumn{2}{|c|}{ Serum CEA level (ng/mL) } \\
\hline Preoperative $\leq 5$ & $428(70.74)$ \\
\hline Preoperative $>5$ & $177(29.26)$ \\
\hline Postoperative $\leq 5$ & $536(88.60)$ \\
\hline Postoperative $>5$ & $69(11.40)$ \\
\hline \multicolumn{2}{|l|}{ Period $^{\mathrm{a}}(w \mathrm{w})$} \\
\hline$\leq 2$ & $11(1.80)$ \\
\hline $2<, \leq 3$ & $62(10.20)$ \\
\hline $3<, \leq 4$ & $532(87.90)$ \\
\hline \multicolumn{2}{|c|}{ Histologic differentiation } \\
\hline Well & $102(16.86)$ \\
\hline Moderately & $448(74.05)$ \\
\hline Poorly & $31(5.12)$ \\
\hline Mucinous & $22(3.64)$ \\
\hline Signet ring cell & $2(0.33)$ \\
\hline \multicolumn{2}{|c|}{ Lymphovascular invasion } \\
\hline Negative & $340(56.20)$ \\
\hline Positive & $265(43.80)$ \\
\hline \multicolumn{2}{|l|}{ T stage } \\
\hline $\mathrm{T} 1$ & $65(10.60)$ \\
\hline $\mathrm{T} 2$ & $52(8.61)$ \\
\hline Т3 & 465 (76.99) \\
\hline $\mathrm{T} 4$ & $23(3.81)$ \\
\hline \multicolumn{2}{|l|}{ N stage } \\
\hline NO & $366(60.50)$ \\
\hline N1 & $149(24.63)$ \\
\hline N2 & $90(14.88)$ \\
\hline \multicolumn{2}{|l|}{ Stage } \\
\hline I & $101(16.69)$ \\
\hline$\|$ & $264(43.64)$ \\
\hline III & $240(39.67)$ \\
\hline
\end{tabular}

Values are presented as number (\%).

CEA, carcinoembryonic antigen.

aPeriod of measurement for postoperative serum CEA level. 
patients (11.4\%) had an abnormal CEA level (>5 ng/mL) after primary resection of the colon cancer. The postoperative serum CEA level was normal $(\leq 5 \mathrm{ng} / \mathrm{mL})$ in 536 patients $(88.6 \%)$. Postoperative serum CEA level was measured between 3 and 4 weeks after surgical resection in almost all patients (87.9\%). The American Joint Committee on Cancer system was used for staging [12] and yielded the following final pathologic tumor stages: stage I, 101 patients (16.69\%); stage II, 264 patients (43.64\%); and stage III, 240 patients (39.67\%) (Table 1). Patients with vascular or lymphatic invasion $(\mathrm{P}=0.0003)$, high grade $\mathrm{pT}$ stage $(\mathrm{P}<0.0001)$, high grade $\mathrm{pN}$ stage $(\mathrm{P}<0.0001)$ and advanced stage $(\mathrm{P}<0.0001)$

Table 2. Clinicopathological characteristics according to preoperative serum CEA group $(\mathrm{n}=605)$

\begin{tabular}{|c|c|c|c|}
\hline \multirow{2}{*}{ Characteristic } & \multicolumn{2}{|c|}{ Preoperative CEA (ng/mL) } & \multirow{2}{*}{ P-value } \\
\hline & $\leq 5$ & $>5$ & \\
\hline Sex & & & 0.8165 \\
\hline Female & $191(44.73)$ & $81(45.76)$ & \\
\hline Male & $237(55.27)$ & $96(54.24)$ & \\
\hline Age (yr) & & & 0.5160 \\
\hline$<59$ & $157(36.68)$ & $60(33.90)$ & \\
\hline$\geq 60$ & 271 (63.32) & $117(66.10)$ & \\
\hline Histologic differentiation & & & 0.1285 \\
\hline Well & $83(19.39)$ & $20(11.30)$ & \\
\hline Moderately & $308(71.96)$ & 139 (78.53) & \\
\hline Poorly & $23(5.37)$ & $8(4.52)$ & \\
\hline Mucinous & $13(3.04)$ & $9(5.08)$ & \\
\hline Signet ring cell & $1(0.24)$ & $1(0.56)$ & \\
\hline Lymphovascular invasion & & & 0.0003 \\
\hline Negative & 261 (60.98) & $79(44.63)$ & \\
\hline Positive & 167 (39.02) & $98(55.37)$ & \\
\hline T stage & & & $<0.0001$ \\
\hline $\mathrm{T} 1$ & 59 (13.79) & $6(3.39)$ & \\
\hline T2 & $45(10.51)$ & 7 (3.95) & \\
\hline T3 & $317(74.07)$ & $148(83.62)$ & \\
\hline T4 & $7(1.63)$ & $16(9.04)$ & \\
\hline N stage & & & $<0.0001$ \\
\hline NO & $282(65.89)$ & $84(47.46)$ & \\
\hline N1 & $95(22.20)$ & $54(30.51)$ & \\
\hline N2 & $51(11.92)$ & $39(22.03)$ & \\
\hline Stage & & & $<0.0001$ \\
\hline I & $93(21.73)$ & $8(4.52)$ & \\
\hline$\|$ & $189(44.16)$ & $75(42.37)$ & \\
\hline III & 146 (34.11) & 94 (53.11) & \\
\hline
\end{tabular}

Values are presented as number (\%). CEA, carcinoembryonic antigen. were significantly more associated with increased preoperative CEA levels (Table 2).

\section{Cutoff value for the decreased rate of perioperative serum CEA level}

To predict the risk of death, we measured the area under the curve of the receiver operating characteristic curve and calculated the cutoff value with maximum sensitivity and specificity in terms of the perioperative rate of decrease in the serum CEA level. The "cutoff values" for the perioperative rate of decrease in the serum CEA level that determined the OS and the DFS were $48.9 \%$ and $50.8 \%$, respectively.

\section{Analysis of OS, DFS and prognostic factors}

In the univariate analysis of a preoperative serum CEA level of $>5$ $\mathrm{ng} / \mathrm{mL}$, prognostic factors for the OS and the DFS were the cutoff value $(\mathrm{P}<0.0001)$, $\mathrm{pN}$ stage $(\mathrm{P}<0.0001)$ and stage $(\mathrm{P}=0.0172)$ (Table 3). Meaningful factors in the univariate analysis were included in the multivariate analysis. In the multivariate analysis of a preoperative serum CEA level of $>5 \mathrm{ng} / \mathrm{mL}$, prognostic factors for the OS and the DFS were the cut-off value $(\mathrm{P}<0.0001)$ and $\mathrm{pN}$ stage $(\mathrm{P}<0.0001)$ (Table 4$)$. Our analyses were based on the following groups:

Group A: preoperative serum CEA of $\leq 5 \mathrm{ng} / \mathrm{mL}$, group B: preoperative serum CEA of $>5 \mathrm{ng} / \mathrm{mL}$, group C: preoperative serum CEA of $>5 \mathrm{ng} / \mathrm{mL}$ and postoperative serum CEA of $\leq 5 \mathrm{ng} / \mathrm{mL}$, group D: preoperative serum CEA of $>5 \mathrm{ng} / \mathrm{mL}$ and postoperative serum CEA of $>5 \mathrm{ng} / \mathrm{mL}$, group E: preoperative serum CEA of $>5 \mathrm{ng} / \mathrm{mL}$ and below the cutoff value relative to the OS, group F: preoperative serum CEA of $>5 \mathrm{ng} / \mathrm{mL}$ and in excess of the cutoff value relative to the OS, group G: preoperative serum CEA of $>5 \mathrm{ng} / \mathrm{mL}$ and below the cutoff value relative to the DFS, group $\mathrm{H}$ : preoperative serum CEA of $>5 \mathrm{ng} / \mathrm{mL}$ and in excess of the cutoff value relative to the DFS.

The estimated 5-year OS and DFS rates for group A vs. B were $82.69 \%$ vs. $63.84 \%(\mathrm{P}<0.001)$ and $78.78 \%$ vs. $59.50 \%$, respectively $(\mathrm{P}<0.001)$. The estimated 5-year OS and DFS rates for group $\mathrm{C}$ vs. $\mathrm{D}$ were $79.37 \%$ vs. $25.49 \%(\mathrm{P}<0.001)$ and $73.61 \%$ vs. $24 \%$, respectively $(\mathrm{P}<0.001)$. The "cutoff values" of the perioperative CEA decrease rates that determined the 5-year OS and DFS rates were $48.9 \%$ and $50.8 \%$, respectively. The estimated 5 -year OS rates for group $\mathrm{E}$ vs. F were $31.37 \%$ vs. $76.98 \%$, respectively $(\mathrm{P}<0.001)$ (Fig. 1). The estimated 5-year DFS rates for group G vs. H were $27.69 \%$ vs. $72.10 \%$, respectively $(\mathrm{P}<0.001)$ (Fig. 2$)$. We analyzed four groups (groups $\mathrm{E}-\mathrm{H}$ ) for each $\mathrm{pN}$ stage. In the analysis of each group for the same $\mathrm{pN}$ stage, group $\mathrm{E}$ showed a better OS than group F (Fig. 1), and group G showed a better DFS than group H (Fig. 2).

\section{DISCUSSION}

Molecular and biochemical markers of CRC are currently being 
Table 3. Univariate analysis of prognostic factors for a preoperative CEA level $>5 \mathrm{ng} / \mathrm{mL}$

\begin{tabular}{|c|c|c|c|c|c|c|}
\hline \multirow[b]{2}{*}{ Factor } & \multicolumn{3}{|c|}{ Overall survival rate } & \multicolumn{3}{|c|}{ Disease-free survival rate } \\
\hline & $\begin{array}{l}5 \text {-yr death } \\
\text { rate }(\%)\end{array}$ & Univariate $^{\mathrm{a}}$ & $\mathrm{HR}(95 \% \mathrm{Cl})$ & $\begin{array}{l}5 \text {-yr recurrence } \\
\text { rate }(\%)\end{array}$ & Univariate $^{\mathrm{a}}$ & $\mathrm{HR}(95 \% \mathrm{Cl})$ \\
\hline \multicolumn{7}{|l|}{ Sex } \\
\hline Male & 30.9 & 0.2793 & Ref & 33.3 & 0.1619 & Ref \\
\hline Female & 40.6 & & $1.320(0.799-2.181)$ & 46.9 & & $1.408(0.872-2.274)$ \\
\hline \multicolumn{7}{|l|}{ Age (yr) } \\
\hline$<60$ & 31.7 & 0.4032 & Ref & 31.7 & 0.0953 & Ref \\
\hline$>59$ & 38.5 & & $1.257(0.735-2.149)$ & 45.3 & & $1.576(0.923-2.691)$ \\
\hline \multicolumn{7}{|c|}{ CEA decrease rate (\%) } \\
\hline$>48.9564$ & 23.0 & $<0.0001$ & Ref & & & \\
\hline$\leq 48.9564$ & 68.6 & & 4.775 (2.906-7.846) & & & \\
\hline \multicolumn{7}{|c|}{ CEA decrease rate (\%) } \\
\hline$>50.8079$ & & & & 27.2 & $<0.0001$ & Ref \\
\hline$\leq 50.8079$ & & & & 73.1 & & $4.441(2.776-7.105)$ \\
\hline \multicolumn{7}{|c|}{ Histologic differentiation } \\
\hline Well & 30.0 & 0.6399 & Ref & 30.0 & 0.5212 & Ref \\
\hline Moderately & 37.0 & & $1.267(0.544-2.951)$ & 42.0 & & $1.716(0.688-4.281)$ \\
\hline Poorly & 37.5 & & $1.421(0.355-5.684)$ & 37.5 & & $1.618(0.387-6.770)$ \\
\hline Mucinous & 25.0 & & $0.776(0.157-3.847)$ & 37.5 & & $1.371(0.327-5.738)$ \\
\hline Signet ring cell & 100.0 & & $4.664(0.557-39.082)$ & 100.0 & & $6.330(0.731-54.845)$ \\
\hline \multicolumn{7}{|c|}{ Lympho-vascular invasion } \\
\hline Negative & 39.2 & 0.4952 & Ref & 40.5 & 0.8612 & Ref \\
\hline Positive & 33.7 & & $0.843(0.516-1.377)$ & 40.8 & & $1.043(0.652-1.667)$ \\
\hline \multicolumn{7}{|l|}{ T stage } \\
\hline $\mathrm{T} 1$ & 0 & 0.5413 & - & 16.7 & 0.5684 & Ref \\
\hline T2 & 14.3 & & Ref & 28.6 & & $1.912(0.173-21.084)$ \\
\hline T3 & 37.2 & & $2.895(0.401-0.923)$ & 41.2 & & $3.225(0.447-23.275)$ \\
\hline $\mathrm{T} 4$ & 50.0 & & $4.179(0.523-3.424)$ & 50.0 & & $3.687(0.453-29.988)$ \\
\hline \multicolumn{7}{|l|}{ N stage } \\
\hline No & 23.8 & 0.0001 & Ref & 26.2 & 0.0002 & Ref \\
\hline N1 & 40.7 & & $1.998(1.090-3.663)$ & 51.9 & & $2.448(1.393-4.300)$ \\
\hline N2 & 56.4 & & $3.719(2.024-6.830)$ & 56.4 & & $3.342(1.848-6.044)$ \\
\hline \multicolumn{7}{|l|}{ Stage } \\
\hline 1 & 0 & 0.0172 & - & 0 & 0.0172 & - \\
\hline$\|$ & 25.7 & & Ref & 28.4 & & Ref \\
\hline III & 44.9 & & 2.215 (1.282-3.828) & 51.7 & & 2.215 (1.282-3.828) \\
\hline
\end{tabular}

CEA, carcinoembryonic antigen; HR, hazard ratio; $\mathrm{Cl}$, confidence interval.

anivariate analysis P-value.

used to investigate several prognostic factors. However, the studies of these markers are complicated, expensive, and of limited clinical relevance. Therefore, CEA levels, which can be easily determined using a simple blood test before and after surgery, are widely used as prognostic factors in patients with CRC. CEA is the most widely accepted and frequently used tumor marker worldwide in patients with CRC, and the method of measurement is standardized, readily available, and inexpensive. In 1999, the College of 
Volume 29, Number 3, 2013

Annals of Coloproctol 2013;29(3):115-122

Table 4. Multivariate analysis of prognostic factors for a preoperative CEA level $>5 \mathrm{ng} / \mathrm{mL}$

\begin{tabular}{|c|c|c|c|c|c|c|}
\hline \multirow[b]{2}{*}{ Factor } & \multicolumn{3}{|c|}{ Overall survival rate } & \multicolumn{3}{|c|}{ Disease-free survival rate } \\
\hline & $\begin{array}{l}5 \text {-yr death } \\
\text { rate }(\%)\end{array}$ & Multivariate $^{\mathrm{a}}$ & $\mathrm{HR}(95 \% \mathrm{Cl})$ & $\begin{array}{c}5 \text {-yr recurrence } \\
\text { rate }(\%)\end{array}$ & Multivariate $^{\mathrm{a}}$ & $\mathrm{HR}(95 \% \mathrm{Cl})$ \\
\hline \multicolumn{7}{|c|}{ CEA decrease rate (\%) } \\
\hline$>48.9564$ & 23.0 & $<0.0001$ & Ref & & & \\
\hline$\leq 48.9564$ & 68.6 & & $4.951(2.997-8.180)$ & & & \\
\hline \multicolumn{7}{|c|}{ CEA decrease rate (\%) } \\
\hline$>50.8079$ & & & & 27.2 & $<0.0001$ & Ref \\
\hline$\leq 50.8079$ & & & & 73.1 & & $4.818(2.998-7.744)$ \\
\hline \multicolumn{7}{|l|}{ N stage } \\
\hline NO & 23.8 & $<0.0001$ & Ref & 26.2 & $<0.0001$ & Ref \\
\hline N1 & 40.7 & & $2.032(1.170-3.729)$ & 51.9 & & $2.666(1.515-4.690)$ \\
\hline N2 & 56.4 & & 3.914 (2.116-7.242) & 56.4 & & 3.715 (2.043-6.755) \\
\hline
\end{tabular}

$\mathrm{CEA}$, carcinoembryonic antigen; $\mathrm{HR}$, hazard ratio; $\mathrm{Cl}$, confidence interval.

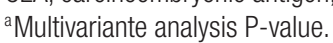
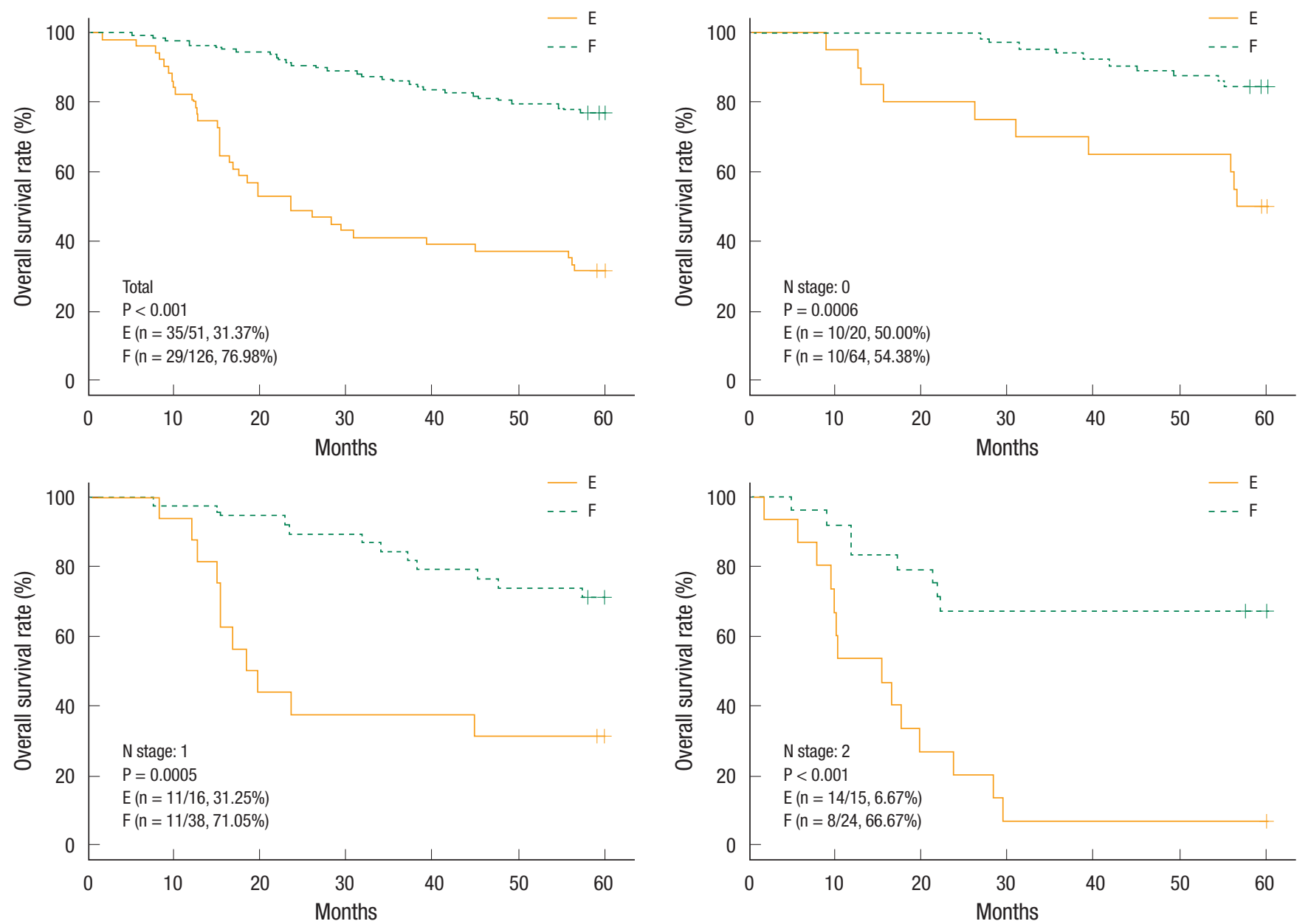

Fig. 1. Analysis of the overall survival in group E vs. F. 

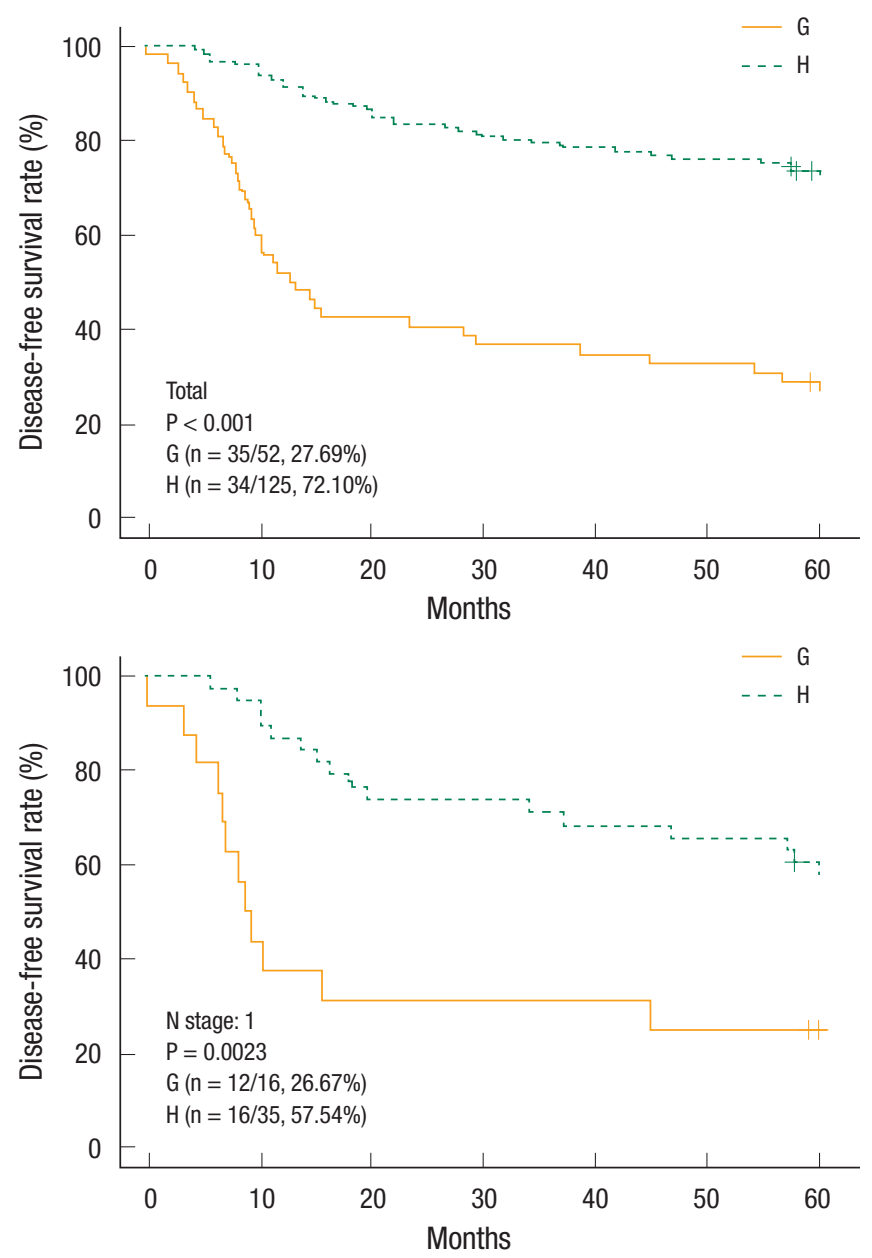

Fig. 2. Analysis of the disease-free survival in group G vs. H.

American Pathologists Consensus Statement classified the prognostic factors of CRC based on the published evidence. It suggested that preoperative CEA elevation be classified into category 1 , together with tumor extent, regional lymph node metastasis, lymphovascular invasion, and residual tumor, after surgery [13]. Most studies of CEA in CRC have focused on the prognostic effect of preoperative CEA levels and on the usefulness of postoperative CEA monitoring for early detection of recurrence after curative surgery and for assessment of the response to chemotherapy in metastatic CRC [14-17].

However, there are few studies of the effect of postoperative serum CEA level on the recurrence rate after a curative resection of colon cancer. A few studies have evaluated the relationship between perioperative serum CEA changes and the prognoses in patients with CRC [18-22]. Park et al. [21] reported that in patients with stage III CRC, the perioperative serum CEA changes were predictive of systemic recurrence and prognosis, and the preoperative and early postoperative serum CEA levels were useful prognostic indicators.

Our data showed that the group with a preoperative serum CEA
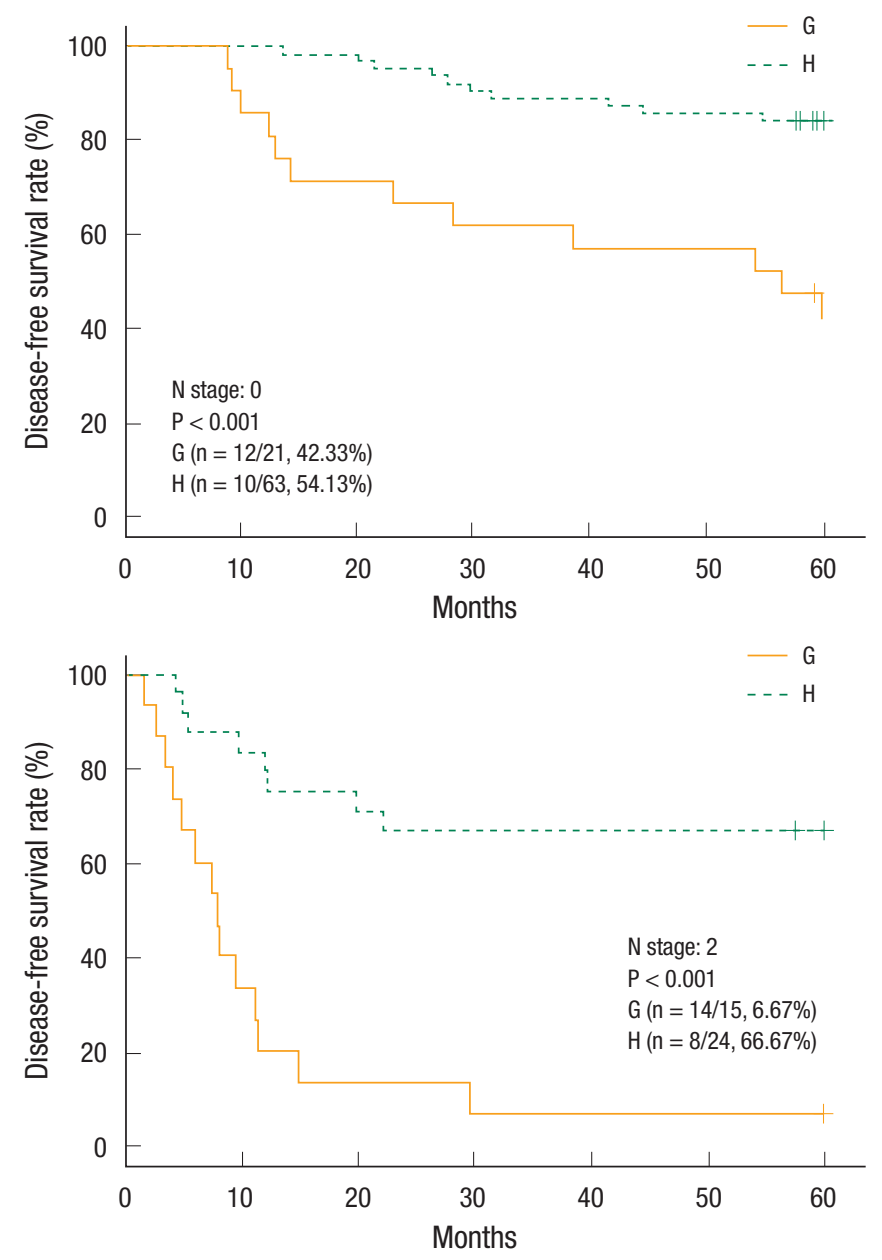

level of $>5 \mathrm{ng} / \mathrm{mL}$ had a more advanced stage and more positive lymphovascular invasion than the group with a preoperative serum CEA level of $\leq 5 \mathrm{ng} / \mathrm{mL}$ and that the majority of the patients had stages II and III disease. Unlike other studies, this study analyzed association of the rate of decrease in the perioperative serum CEA level and its cutoff value with the survival rate. In the group with a preoperative serum CEA of $>5 \mathrm{ng} / \mathrm{mL}$, the cutoff values related to the OS and the DFS were $48.9 \%$ and $50.8 \%$, respectively. In the multivariate analysis for the prognostic factors, the cutoff values related to the OS and the DFS showed hazard ratios of 4.951 (95\% confidence interval, 2.997 to 8.180$)(\mathrm{P}<0.0001)$ and 4.818 (95\% confidence interval, 2.998 to 7.744$)(\mathrm{P}<0.0001)$, respectively. Known prognostic factors for colon cancer were the preoperative serum CEA level, $\mathrm{pT}$ stage, $\mathrm{pN}$ stage, and lymphovascular invasion. However, in our study the cutoff values and the $\mathrm{pN}$ stage were prognostic factors for the OS and the DFS. We think that our results were different from other studies because we analyzed the group with preoperative serum CEA $>5 \mathrm{ng} / \mathrm{mL}$, for which a poor prognosis is expected.

When the groups were divided according to a preoperative se- 
rum CEA level of $5 \mathrm{ng} / \mathrm{mL}$, the 5 -year OS rates for the $\leq 5$ and $>5$ $\mathrm{ng} / \mathrm{mL}$ groups were $82.69 \%$ and $63.84 \%$, respectively $(\mathrm{P}<0.0001)$, and the 5 -year DFS rates for the $\leq 5$ and $>5 \mathrm{ng} / \mathrm{mL}$ groups were $78.78 \%$ and $59.50 \%$, respectively $(\mathrm{P}<0.0001)$. Therefore, the preoperative serum CEA level was a prognostic factor for survival, as previously shown.

The group with a preoperative serum CEA level of $>5 \mathrm{ng} / \mathrm{mL}$ was expected to have a poorer outcome. The group with a postoperative serum CEA level that returned to the normal range (group C) showed superior OS and DFS compared with the group with a CEA level that did not return to the normal range. This is similar to the conclusions of Park et al. [21]. Therefore, we suspected that patients with a preoperative serum CEA level of $>5 \mathrm{ng} / \mathrm{mL}$ would have a good prognosis in terms of the postoperative serum CEA level being reduced compared with preoperative value. We analyzed the "cutoff value" of the perioperative serum CEA decrease rate that determined the OS and the DFS in patients with a preoperative serum CEA level of $>5 \mathrm{ng} / \mathrm{mL}$. The 5 -year OS rates for patients with a level above the cutoff value and for those with a level below the cutoff value were $76.98 \%$ and $31.37 \%$, respectively $(\mathrm{P}<0.0001)$. The 5 -year DFS rates for patients with a level above the cutoff value and for those with a level below the cutoff value were $72.10 \%$ and $27.69 \%$, respectively $(\mathrm{P}<0.0001)$.

The present study was limited by its retrospective design and by the fact that the time of postoperative blood sampling for the CEA measurement was not consistent, ranging from 1 to 4 weeks after surgery.

In conclusion, normalization of the postoperative serum CEA level and a reduction in excess of $50 \%$ in the perioperative rate of decrease in the serum CEA level may be used as a prognostic marker for survival in patients with a preoperatively-elevated CEA level. In addition, if the perioperative rate of decrease in the serum CEA level is not satisfactory, new follow-up strategies will be planned.

\section{CONFLICT OF INTEREST}

No potential conflict of interest relevant to this article was reported.

\section{REFERENCES}

1. Macdonald JS. Adjuvant therapy of colon cancer. CA Cancer J Clin 1999;49:202-19.

2. Greene FL, Balch CM, Fleming ID, editors. AJCC cancer staging handbook: TNM classification of malignant tumors. 6th ed. New York: Springer; 2002.

3. Wang JY, Lu CY, Chu KS, Ma CJ, Wu DC, Tsai HL, et al. Prognostic significance of pre- and postoperative serum carcinoembryonic antigen levels in patients with colorectal cancer. Eur Surg Res 2007;39:245-50.

4. Klee GG, Go VJW. Carcinoembryonic antigen and its role in clinical practice. In: Ghosh BC, Ghosh L, editors. Tumor markers and tumor-associated antigens. New York: Mc-Graw-Hill; 1990. p. $22-43$.

5. Arfa N, Hamdani I, Gharbi L, Ben Abid S, Ghariani B, Mannai S, et al. Survival and prognostic factors of colorectal adenocarcinoma: analytic multifactor review of 150 cases. Ann Chir 2006;131: 104-11.

6. Wang WS, Lin JK, Chiou TJ, Liu JH, Fan FS, Yen CC, et al. Preoperative carcinoembryonic antigen level as an independent prognostic factor in colorectal cancer: Taiwan experience. Jpn J Clin Oncol 2000;30:12-6.

7. Gold P, Freedman SO. Specific carcinoembryonic antigens of the human digestive system. J Exp Med 1965;122:467-81.

8. Ahnen DJ, Feigl P, Quan G, Fenoglio-Preiser C, Lovato LC, Bunn $\mathrm{PA}$ Jr, et al. Ki-ras mutation and p53 overexpression predict the clinical behavior of colorectal cancer: a Southwest Oncology Group study. Cancer Res 1998;58:1149-58.

9. Chen CC, Yang SH, Lin JK, Lin TC, Chen WS, Jiang JK, et al. Is it reasonable to add preoperative serum level of CEA and CA19-9 to staging for colorectal cancer? J Surg Res 2005;124:169-74.

10. Moertel CG, O'Fallon JR, Go VL, O'Connell MJ, Thynne GS. The preoperative carcinoembryonic antigen test in the diagnosis, staging, and prognosis of colorectal cancer. Cancer 1986;58:603-10.

11. Steele G Jr, Osteen RT, Wilson RE, Brooks DC, Mayer RJ, Zamcheck N, et al. Patterns of failure after surgical cure of large liver tumors. A change in the proximate cause of death and a need for effective systemic adjuvant therapy. Am J Surg 1984;147:554-9.

12. Edge SB, Byrd DR, Compton CC, Fritz AG, Greene FL, Trotti A, editors. AJCC cancer staging manual. 7th ed. New York: Springer; 2010.

13. Compton CC, Fielding LP, Burgart LJ, Conley B, Cooper HS, Hamilton SR, et al. Prognostic factors in colorectal cancer. College of American Pathologists Consensus Statement 1999. Arch Pathol Lab Med 2000;124:979-94.

14. Quentmeier A, Schlag P, Hohenberger P, Schwarz V, Abel U. Assessment of serial carcinoembryonic antigen: determinations to monitor the therapeutic progress and prognosis of metastatic liver disease treated by regional chemotherapy. J Surg Oncol 1989;40: 112-8.

15. Bruinvels DJ, Stiggelbout AM, Kievit J, van Houwelingen HC, Habbema JD, van de Velde CJ. Follow-up of patients with colorectal cancer. A meta-analysis. Ann Surg 1994;219:174-82.

16. Sugarbaker PH, Gianola FJ, Dwyer A, Neuman NR. A simplified plan for follow-up of patients with colon and rectal cancer supported by prospective studies of laboratory and radiologic test results. Surgery 1987;102:79-87.

17. Tate H. Plasma CEA in the post-surgical monitoring of colorectal carcinoma. Br J Cancer 1982;46:323-30.

18. Slentz K, Senagore A, Hibbert J, Mazier WP, Talbott TM. Can preoperative and postoperative CEA predict survival after colon cancer resection? Am Surg 1994;60:528-31.

19. Oh JH, MacLean LD. Prognostic use of preoperative and immediate postoperative carcinoembryonic antigen determinations in colonic cancer. Can J Surg 1977;20:64-7. 


\section{Coloproctology Tae Doo Jung, et al.}

20. Behr TM, Sharkey RM, Juweid MI, Dunn RM, Ying Z, Zhang $\mathrm{CH}$, et al. Factors influencing the pharmacokinetics, dosimetry, and diagnostic accuracy of radioimmunodetection and radioimmunotherapy of carcinoembryonic antigen-expressing tumors. Cancer Res 1996;56:1805-16.

21. Park YA, Lee KY, Kim NK, Baik SH, Sohn SK, Cho CW. Prognos- tic effect of perioperative change of serum carcinoembryonic antigen level: a useful tool for detection of systemic recurrence in rectal cancer. Ann Surg Oncol 2006;13:645-50.

22. Lee WS, Baek JH, Kim KK, Park YH. The prognostic significant of percentage drop in serum CEA post curative resection for colon cancer. Surg Oncol 2012;21:45-51. 